\title{
HISTORY OF THE DISPOSSESSION OF THE RIGHTS IN LAND OF PASTORAL INDIGENOUS COMMUNITIES IN THE CAPE COLONY FROM 1652 TO 1910
}

\author{
JN McLachlan*
}

\section{ABSTRACT}

The pastoral indigenous communities living in southern Africa at the start of the colonial period were the first to be dispossessed of their rights in land. They had exercised these rights in terms of their customary law systems for centuries before the arrival of non-indigenous settlers in 1652. During the nineteenth century, the final acts of dispossession of land took place in terms of racially discriminatory legislation and administrative actions, just like the dispossession of land that took place after 19 June 1913. However, the descendants of these communities are unable to claim restoration of their rights in land in terms of the constitutional land reform programme. This contribution identifies the customary law rights in land of these communities and compares such rights with the rights that non-indigenous settlers had in the land used as grazing on loan places. This comparison shows that the rights in land used

* BA (Stell) LLB LLM (RAU) LLD (Pretoria); advocate of the High Court, state law adviser in the Office of the Chief State Law Adviser. This contribution is based on parts of my doctoral thesis entitled The History of the Occupation of Land in the Cape Colony and the Effect Thereof on Land Law and Constitutionally Mandated Land Reform (University of Pretoria, 2019). 


\begin{abstract}
as grazing of non-indigenous settlers and pastoral indigenous communities were in essence the same. However, from 1813 the colonial government implemented legislation in the Cape Colony that created big disparities with regard to rights in land between them. In this contribution, it is argued that colonial dispossession of land from pastoral indigenous communities should be rectified by adopting legislation in terms of section $25(8)$ of the Constitution that will enable the descendants of these communities to claim restoration of their ancestral land.
\end{abstract}

Keywords: pastoral; indigenous; customary law; perpetual quitrent; settlers

\title{
1 Introduction
}

The first indigenous communities ${ }^{1}$ to be dispossessed of their customary law rights in land in southern Africa were the pastoral indigenous communities ${ }^{2}$ living in the southwestern, southern and north-western parts of the Cape Colony. ${ }^{3}$ The descendants of some of these communities still live in the north-western and western parts of what is now respectively the Western Cape and Northern Cape Provinces, and still occupy land in terms of customary law principles. ${ }^{4}$ As the dispossession of the rights in land of these communities took place before 19 June $1913^{5}$ the Constitution ${ }^{6}$ and the Restitution of Land Rights Act ${ }^{7}$ (Restitution Act) do not provide for the restitution of such rights. In this contribution it is contended that the exclusion of the descendants

1 The contentious issue of who may be regarded as indigenous people in South Africa is not addressed in this contribution. The persons and communities that were or are holders of rights in land under customary law systems are referred to as indigenous people or indigenous communities.

2 For the purposes of this contribution "pastoral indigenous communities" means indigenous communities that only kept livestock and did not cultivate the land.

3 In this contribution, the Cape means the Cape Peninsula and Table Valley that are separated from the interior of the country by the Cape Flats, and a small area along the west coast up to Saldanha Bay. The Cape Colony refers to the territory as it gradually developed beyond the Cape, not only to the Colony as it existed when the Union of South Africa was formed in 1910. The meaning of the phrase is therefore determined by the period that is being dealt with at that stage. The phrase "interior of the Cape Colony" refers to the areas beyond the permanent settlement area comprising the arid areas north and north-east of the Cape. The phrase "permanent settlement areas" means the areas where there were colonial government buildings and non-indigenous settlers' houses, like the area where Cape Town was starting to develop and areas where the non-indigenous settlers had farms.

4 This contribution deals specifically with the pastoral indigenous communities who lived in the region that was known as Namaqualand during the colonial period and with their descendants who currently live in the area under the jurisdiction of the Namakwa District Municipality.

5 This is the date on which the Natives Land Act 27 of 1913 entered into force. In terms of s 121(3) of the interim Constitution of the Republic of South Africa 200 of 1993 the date for restitution of land may not be earlier than 19 Jun 1913. This date is referred to in this article as the cut-off date.

6 Constitution of the Republic of South Africa, 1996.

7 Act 22 of 1994. 
of pastoral indigenous communities that lived in the north-western Cape Colony from the land restitution sub-programme ${ }^{8}$ leads to unequal treatment of dispossessed persons in democratic South Africa. ${ }^{9}$

In this contribution it is argued that the customary law rights in land of the descendants of the dispossessed pastoral indigenous communities should be restored provided that they -

(a) are still living in the relevant areas that are referred to in Schedule 2 to the Rural Areas Act (House of Representatives) (Rural Areas Act); ${ }^{10}$ and

(b) still utilise land used as grazing in terms of the customary law system of their ancestors.

Section 2 deals with the customary law systems of pastoral indigenous communities and their rights in land in terms of these systems. The manner in which the residents

8 In the rest of this contribution I refer to this area as the north-western Cape. The restitution subprogramme forms part of the constitutional land reform programme provided for in s 25 of the Constitution and is dealt with in subs (7) of said s.

9 The Transformation of Certain Rural Areas Act 94 of 1998 (Transformation Act) makes provision for the redistribution of land in, amongst other areas, the Namakwaland District Municipality, but does not provide for the restitution of the customary law rights in land dispossessed during the colonial period.

10 Act 9 of 1987. Schedule 2 provides as follows:

\begin{tabular}{|l|l|}
\hline \multicolumn{1}{|c|}{ Area } & \multicolumn{1}{c|}{ Description of Area } \\
\hline 1. Concordia & As defined in paragraph D of the Schedule to Proclamation 53 of 1912. \\
\hline 2. Ebenezer & As defined in the Schedule to Proclamation 222 of 1964. \\
\hline 3. Komaggas & $\begin{array}{l}\text { As defined in paragraph B of the Schedule to Proclamation 53 of 1912, } \\
\text { together with the farm Bontekoe as defined by Proclamation } 333 \text { of } \\
1960 .\end{array}$ \\
\hline 5. Leliefontein & $\begin{array}{l}\text { As defined in paragraph A of the Schedule to Proclamation 53 of 1912, } \\
\text { together with the farms Tweerivieren and Hoorngat as defined by } \\
\text { Proclamation 114 of 1960. }\end{array}$ \\
\hline 6. & \\
\hline 7. & \\
\hline 8. & As defined in the Schedule to Proclamation 182 of 1957. \\
\hline 9. Richtersveld & \\
\hline 10. & $\begin{array}{l}\text { As defined in paragraph C of the Schedule to Proclamation 53 of 1912, } \\
\text { together with the farm Wolftoen as defined by Proclamation 94 of 1962. }\end{array}$ \\
\hline 11. & \\
\hline 12. Steinkopf & \\
\hline 13. & [Item 14 added by Proclamation No 162 of 1989] \\
\hline 14. &
\end{tabular}

The specific areas dealt with in this contribution are referred to as the Reserves and are listed as items $1,4,5,9$ and 12 in the Table. 
of the Reserves continue to occupy land used as grazing in terms of customary law systems is also discussed. ${ }^{11}$

Section 3 deals with the rights in land of non-indigenous settlers ${ }^{12}$ that are comparable with the customary law rights of pastoral indigenous communities. The non-indigenous settlers concerned occupied land used as grazing on loan places in the interior of the Cape Colony.

The discussion of pastoral indigenous communities' and non-indigenous settlers' rights in land used as grazing serves as the background for the discussion in section 4. This section deals with the legislation and administrative measures introduced into the Cape Colony from 1813 that made it possible for the colonial government to survey and demarcate land, ${ }^{13}$ and grant, sell and lease the land units to non-indigenous settlers. As the residents of the Reserves were eventually prevented from exercising their customary law rights on land occupied by their ancestors in terms of customary law systems, they were dispossessed of their rights by the abovementioned legislation and administrative measures.

The colonial government was able to introduce the legislation and administrative measures referred to above because the English common law doctrine of tenures was made part of the domestic law of the Cape Colony after $1813 .{ }^{14}$ The introduction of

11 This discussion deals mainly with the manner in which the residents of the Leliefontein Reserve still occupy the communal land on that Reserve with their livestock. This is due to the fact that the majority of the research regarding the utilisation of grazing in the semi-arid Namakwaland district has been done at Leliefontein.

12 In this contribution the phrase "non-indigenous persons" refers to natural and legal persons who cannot be regarded as indigenous persons as contemplated in $\mathrm{n} 1$ and who acquired their rights in land in terms of the domestic law of the Cape Colony. The phrase "non-indigenous settlers" refers to persons who left the service of the Dutch East India Company (Company) to conduct farming operations for their own account, and their descendants, as well as non-indigenous immigrants, like the French Huguenots, who were not employees of the Company. It is contended that there is a difference between the common law of the Cape Colony in the colonial period and the law that is today known as the common law of South Africa. It is not contended that Roman-Dutch law was not introduced in the Cape Colony in 1652 or that it was not the basis of property law in the Cape Colony. Roman-Dutch law of property principles were applied in situations that were familiar to the colonial government and non-indigenous settlers. However, the colonial government was confronted with circumstances relating to the occupation of land in which conventional RomanDutch law principles could not be applied. Consequently, it adopted measures to address these circumstances that gradually became customs in the Cape Colony, or published plakate (local laws) to address the problem. These customs and plakate formed part of the legal system that is referred to as the domestic law of the Cape Colony.

13 Surveyed and demarcated land is referred to as land units in this contribution.

14 The classical formulation of the doctrine reads as follows: "The true meaning of the word fee, feodum, is the same with that of feud or fief, and, in its original sense, it is taken in contradistinction to allodium; which latter the writers on this subject define to be every man's own land, which he possesses merely in his own right, without owing any rent or service to any superior ... But feodum, or fee, is that which is held of some superior on condition of rendering him service; in which superior the ultimate property of the land resides. And, therefore, Sir Henry Spelman defines a feud or fee to be the right which the vassal or tenant has in lands, to use the same, and 
this doctrine had the effect that all land in the Cape Colony not belonging to nonindigenous persons (Crown land) was regarded as the property of the British Crown. In Richtersveld Community v Alexkor Ltd ${ }^{15}$ (Richtersveld 2) the Supreme Court of Appeal (SCA) found that the doctrine was not applicable to land claimed by the Richtersveld community and that they were not dispossessed of their rights in land before 19 June 1913. Section 5 of this contribution deals with the negative effect that the SCA's approach to Crown land has on the customary law rights in land of the residents of the Reserves other than Richtersveld.

In section 6 it is suggested that legislation should be enacted in terms of section 25(8) of the Constitution to redress the dispossession of the rights in land of the ancestors of the current residents of the Reserves during the colonial period.

\section{Key concepts of the customary law systems of pastoral indigenous communities}

Legal historians have not yet written a definitive work specifically on the customary law systems of the pastoral indigenous communities that lived in the territory that became the Cape Colony. ${ }^{16}$ Therefore, to determine the key concepts of these customary law systems the descriptions and approaches offered by historians, archaeologists and anthropologists of the manner in which indigenous communities occupied the land are used. ${ }^{17}$

take the profits thereof to him and his heirs, rendering to the lord his due services: the mere allodial property of the soil always remaining in the lord. This allodial property no subject in England has; it being a received, and now undeniable, principle in the law, that all the lands in England are holden mediately or immediately of the crown. The sovereign, therefore, only has absolutum et directum dominium: but all subjects' lands are in the nature of feodum or fee; whether derived to them by descent from their ancestors, or purchased for a valuable consideration, for they cannot come to any man by either of those ways, unless accompanied with those feudal clogs which were laid upon the first feudatory when it was originally granted. A subject, therefore, has only the usufruct, and not the absolute property of the soil; or, as Sir Edward Coke expresses it, he has dominium utile, but not dominium directum." See Kerr 1876: 88-89.

152003 (6) SA 104 (SCA).

16 The only published work found on the customary law systems of exclusively pastoral indigenous communities in southern Africa, is Hinz \& Grasshoff (eds) 2016.

17 The appropriateness of using this method to determine the content of the customary law rights in land of an indigenous community is confirmed by the Constitutional Court (CC) in Alexkor Ltdv The Richtersveld Community 2004 (5) SA 460 (CC) 481 (Alexkor). In view of the CC's remarks, the facts regarding the use of land that are obtained from histories of indigenous communities are used in this contribution to reach logical conclusions regarding the manner in which the communities exercised their rights in land. 


\section{Basis of pastoral indigenous communities' rights in land}

Yanou describes the relationship between indigenous communities in Africa and the land they occupy as follows: ${ }^{18}$

The right to own property is a very ancient one and speculations on its nature goes [sic] beyond Plato's philosophical views. Africans for instance, customarily regard land as a gift from God or a bequest by the ancestors. Its possession and control is [sic] inextricably linked to the identity of the community such that it is impossible to construe the people without it.

From these remarks it appears that a basic feature of indigenous communities' perception of their right to occupy land ${ }^{19}$ is that it was given to them as a community. It is implicit in this approach that the community may use the land given to them in the manner that it regards as the most beneficial. Pastoral indigenous communities not only had the general right to use the land to sustain themselves by gathering and hunting, but also used specific areas of the land as grazing..$^{20}$ It appears that the fact that pastoral indigenous communities' livestock used specific areas of grazing over a period of time gave them stronger rights in land than nomadic hunter-gatherer indigenous communities. ${ }^{21}$ It is accepted that the different pastoral indigenous communities that lived in a region developed rules that governed which resources each community could use in that region. In view of this development it can be contended that indigenous communities had occupied land for centuries but after

18 Yanou 2005: 89-90.

19 In Alexkor, the CC provides the following guidelines on the manner in which customary law rights must be applied: "It is clear, therefore, that the Constitution acknowledges the originality and distinctiveness of indigenous law as an independent source of norms within the legal system. At the same time the Constitution, while giving force to indigenous law, makes it clear that such law is subject to the Constitution and has to be interpreted in the light of its values. Furthermore, like the common law, indigenous law is subject to any legislation, consistent with the Constitution, that specifically deals with it. In the result, indigenous law feeds into, nourishes, fuses with and becomes part of the amalgam of South African law." See Alexkor Ltd $v$ The Richtersveld Community at 479.

20 Anthropologists refer to the territories occupied by pastoral indigenous communities as nomadic orbits. A nomadic orbit needed the following three essential elements to come into existence: (a) a community; (b) livestock owned by individual members of the community; and (c) locations with water resources and associated grazing between which the community migrated. These characteristics are deduced from the descriptions of nomadic orbits given by Hattingh 2016: 270-288.

21 The rights in land of nomadic hunter-gatherer indigenous communities are not discussed in this contribution as the spatial aspect of the territories they lived in was not determined by physical boundaries but by "organised agreements" between such indigenous communities. See Gilbert 2007: 691. Since they did not own livestock, the nomadic hunter-gatherer lifestyle of indigenous communities meant that the physical extent of the land they used would not have been ascertainable. Also, the extent of the area within which they hunted and gathered could not be determined. 
they acquired livestock and became pastoral indigenous communities they had to use the land subject to their customary law system.

\section{The role of livestock in the customary law systems}

Schapera remarks that land had value for indigenous communities "chiefly as pasture and hunting ground". ${ }^{22}$ Based on this statement it is contended that without livestock indigenous communities did not obtain rights in land as such communities did not need water resources or grazing for their livestock. Communities that did own livestock had to look for the best water resources and grazing wherever these could be found. ${ }^{23}$ Large livestock units, like cattle, required large amounts of grazing. ${ }^{24}$ Therefore, depending on the climate and the fertility of the soil of the region, and the availability of open water, the communities had to move from place to place to ensure that their livestock were adequately cared for. The bigger the herds and flocks the more extensive were the spaces occupied by the community. ${ }^{25}$ Livestock were owned by individuals and not by a community as a whole. The livestock belonging to individuals were often herded together, but this did not mean that the combined herds or flocks were the common property of the community. ${ }^{26}$

\section{The availability of water resources and grazing as determinant of the location of nomadic orbits}

An important feature of nomadic orbits was that they did not have defined boundaries. ${ }^{27}$ Schapera offers the following explanation of how nomadic orbits could exist without defined boundaries: ${ }^{28}$

It appears rather that in the early days of the Dutch settlement the different Hottentot tribes were situated far apart, each tribe forming centres round which it migrated, and claiming as its territory all the land where its members were accustomed to graze their herds or to live.

22 Schapera 1930: 286. As this contribution deals only with pastoral indigenous communities and not indigenous hunter-gatherer communities, the value of land as hunting ground is not taken into account.

23 Elphick 1977: 57.

24 Boonzaier 1996: 29.

25 Elphick 1977: 117-118 substantiates this view with his comparison between the Cochoqua indigenous community and the indigenous communities that lived at or near the Cape Peninsula.

26 Schapera 1930: 293.

27 Idem at 286-287.

28 Idem at 287. 
Over time the practice developed that specific indigenous communities came to be regarded as the primary users of specific water resources. ${ }^{29}$ The limits of the nomadic orbits of the communities were defined by the location of the water resources of which they were the primary users.

\section{Occupation of specific spaces as grazing within nomadic orbits}

The physical spaces within nomadic orbits where indigenous communities exercised their customary law rights must be described without resorting to comparisons with the legal concepts of property and ownership as defined by South African common law. ${ }^{30}$ For the purposes of this contribution these spaces are referred to as communal land use units. These communal land use units had the following characteristics:

(a) The size of the space was determined by the amount of grazing needed by the combined livestock belonging to the members of a community.

(b) The location of the physical space was determined by the location of the water resources where a specific community was acknowledged as being the primary user of such resources.

(c) The boundaries of the land used as grazing by the combined livestock of a community were not fixed.

In view of these characteristics, the said physical spaces may be defined as areas of grazing used by the combined livestock of a community in the vicinity of a

29 Idem at 87. Guelke \& Shell 1992: 807 refer to remarks made by indigenous persons at the conclusion of the 1659 war between the Company and indigenous communities living at the Cape that show that "access to water was a critical factor in the Khoikhoi pastoral economy". Contrary to Guelke's remarks, Elphick 1977:44 contends that the location of water resources as indication of a community's nomadic orbit was only applicable in Namaqualand. He remarks that in the south-western Cape "springs were apparently not of vital significance". Smith 1984: 100 is of the opinion that water was readily available in the south-western Cape and therefore did not play an important role in determining the nomadic orbits of indigenous communities. The remarks referred to by Guelke relate to a specific incident during the 1659 war when Oedasoa, the chief of the indigenous community living in the vicinity of Saldanha Bay, denied the indigenous communities of the Cape access to the best water resources of the area. This was one of the reasons why the Cape indigenous communities were persuaded to seek peace with the Company. Guelke's contention is preferable to that of Elphick and Smith as it reflects the views of persons who had experienced firsthand how water resources were controlled by the community that was the primary user thereof. The phrase "primary users" is used for a community that had the necessary power to prevent another community from using a water resource.

30 This principle has been laid down by the CC in Alexkor Ltd v The Richtersveld Community at 480 481 and in Bhe v Magistrate, Khayelitsha, (Commission for Gender Equality as Amicus Curiae); Shibi v Sithole; South African Human Rights Commission v President of the Republic of South Africa 2005 (1) SA 580 (CC) 640. 
water resource where that community was acknowledged as the primary user of the resource.

As this contribution is specifically concerned with the customary law rights in land of pastoral indigenous communities in the arid north-western Cape it is necessary to point out the differences between the concepts of a nomadic orbit and a communal land use unit. In more arid areas where a water resource could dry up during certain times of the year the indigenous communities had water resources of which they were the primary users in different geographical areas. Such a community could therefore have communal land use units in a winter rainfall area and in a summer rainfall area. The nomadic orbits of indigenous communities are described as covering the whole territory between two such geographical areas. ${ }^{31}$

In view of characteristic (a) of a communal land use unit mentioned above a community could not claim land that it was not using or did not reasonably need to provide sufficient grazing for its combined livestock. In addition to the rights in land used as grazing the community had customary law rights in land on which their encampment stood and where they erected enclosures for the safety of the combined livestock. It did not have these rights in the whole area covered by its nomadic orbit.

\section{Protection of customary law rights in communal land use units}

In arid parts, the control of water resources was the key determinant of a pastoral indigenous community's territorial claims. The fact that a specific community was the primary user of a water resource meant that other indigenous communities had to obtain permission to use that water resource while the primary user was in occupation and control thereof..$^{32}$ This necessarily implied that permission also had to be obtained to use the land as grazing. The primary user could also demand payment of a tribute from another indigenous.

\section{Exercise of customary law rights in land on the Reserves in the twenty-first century}

The customary law systems of the pastoral indigenous communities of the precolonial and colonial eras as described above no longer exist in their pure form. One

31 The nomadic orbit of an indigenous community like the Namaqua covered an enormous territory (see Hattingh 2016: 278), in which there had to be areas that were not suitable for grazing or where there were no water resources. It is therefore reasonable to argue that there were specific areas within this vast territory where they exercised their rights. These were the communal landuse units where indigenous communities exercised their rights in land.

32 See Schapera 1930: 287. It is interesting to note that theorists about how Man first obtained rights in land, like Pufendorf, postulate that even in the time when there was an abundance of resources, there had to be agreement between persons about the taking of basic things from nature that were needed for their survival. See Olivecrona 1974: 221. 
of the factors that contributed to the changes in the customary law systems is the legislation relating to the Reserves that was adopted during the twentieth century. The Mission Stations and Communal Reserves Act ${ }^{33}$ (Mission Stations Act) dealt amongst other things with the land around mission stations that was reserved for the exclusive use of the residents of the mission stations. ${ }^{34}$ The Mission Stations Act was enacted in 1909 and was aimed at removing the control of secular matters from the missionaries at mission stations. Another purpose of the Mission Stations Act was to place the landholding of the residents of the mission stations and communal reserves on a formal footing. ${ }^{35}$ As time progressed during the twentieth century the only land where the descendants of pastoral indigenous communities could exercise their customary law rights was the communal land located in the Reserves. ${ }^{36}$

Currently, the owners of livestock on the Reserves still occupy the communal land used as grazing in terms of customary law systems. The customary law systems followed on the Reserves fall within the definition given by Herbst of such systems: ${ }^{37}$

African customary law in the modern sense of the word (ie, with Western influence):

denotes all those legal systems originating from African societies as part of the culture of particular tribes or groups that have been maintained, supplemented, amended and or superseded in part by:

(a) changing community views and the demands of the changing world;

(b) contact with societies with other legal systems;

(c) contact with and the influence of other legal systems; and

(d) the direct and indirect influence of foreign (non-indigenous) government structures.

33 Act 29 of 1909 (Cape of Good Hope).

34 See the remarks in para 44 regarding the Tickets of Occupation issued by the governor of the Cape Colony, which included a diagram or description of the reserved land.

35 See, in this regard, the long title of the Mission Stations Act, which provided as follows: "To Provide for the better management and control of certain Mission Stations and certain Lands reserved for the occupation of certain Tribes or Communities, and for the granting of titles to the Inhabitants of such Stations and Reserves." See Colony of the Cape of Good Hope Acts of Parliament Sessions of 1908, being the first and second sessions of the twelfth Parliament (1908): 5544. The Union and Republic of South Africa's governments subsequently adopted legislation that repealed the Mission Stations Act and regulated the use of communal land, amongst other matters, on the Reserves created in terms of the Mission Stations Act. See, in this regard, the Rural Coloured Areas Act 24 of 1963, the Rural Coloured Areas Law 1 of 1979 and the Rural Areas Act.

36 The land on the Reserves is still owned by the State, but the Transformation Act has been enacted to facilitate the process of transfer of this land from the State to - (a) a municipality; (b) a communal property association registered in terms of s 8 of the Communal Property Associations Act 28 of 1996; or (c) another body or person approved by the Minister in general or in a particular case. Once the transfer of land in terms of the Transformation Act has been completed, the Rural Areas Act will be repealed.

37 Herbst \& Du Plessis 2008: 3. 
As the residents of the Reserves who own livestock are still able to utilise the rights in land of which their ancestors were dispossessed it is contended that the northern $\mathrm{Cape}^{38}$ is a region where rights in land dispossessed during the colonial period can successfully be reinstated.

In the early 1980s the majority of the residents of Leliefontein ${ }^{39}$ were still maintaining flocks of sheep and goats on the communal land on the Reserve. ${ }^{40}$ Webley remarks that although the boundaries of Leliefontein limited the range within which transhumance could take place, it still played an important role in livestock farming. ${ }^{41}$

The stock posts of Leliefontein are small encampments where herders establish themselves during winter. These encampments are usually situated near a water resource. ${ }^{42}$ Marinus remarks that stock posts serve as the central points of loosely defined grazing areas for specific flocks using the outer commonages of Leliefontein. He is of the opinion that although this is an informal system employed by the residents of Leliefontein the livestock owners and herders are bound by the norms created by the residents with regard to grazing around stock posts. ${ }^{43}$ Marinus is therefore of the opinion that certain Leliefontein families or groups have "preferential access" to the grazing and water resource at a specific stock post. ${ }^{44}$

38 The phrase "northern Cape" does not refer to the Northern Cape Province, but to the area that stretches north from the Olifants River along the West Coast to the Gariep River. See, also, $\mathrm{n} 4$.

39 See the remarks in $\mathrm{n} 11$ with regard to the reasons why the example of Leliefontein and the stock post system there is used in this contribution. For the purposes of this contribution it is accepted that any Reserve where land used as grazing is occupied in terms of the stock post or a similar system, the livestock owners are exercising customary law rights in land.

40 Webley 1986: 57.

41 From Rohde and Hoffman's article, it appears that transhumance was still a feature of stock farming on Leliefontein in the early twenty-first century although it is mostly individuals - or in some instances couples - that accompany the flocks of livestock (see Rohde \& Hoffman 2008: 193). The Oxford English Dictionary defines "transhumance" as "[t]he seasonal transfer of grazing animals to different pastures, often over substantial distances', 'transhumance', n." See OED Online (Mar 2017) available at http://www.oed.com.uplib.idm.oclc.org/view/Entry/204785? redirectedFrom=transhumant (accessed 13 Apr 2019).

42 Webley 1986: 58.

43 Marinus 1998: 597.

44 Idem at 598. The informal manner in which this system of preferential access areas developed on Leliefontein is described as follows by Marinus: "Informal resource entitlement constitute [sic] small groups of up to five stock owners (usually with strong kinship links between them) migrating with their herds within loosely defined tracts of land adjacent to the settlements where they live (Boonzaier 1987: 481, Archer 1995: 32). Thus specific families or groups have preferential access to certain areas, which are established informally and through long association. Some tracts of land, waterholes and springs have always been regarded as 'belonging' to certain lineages. (The claim to these areas has never been one of exclusive ownership as fellow community members are granted usufruct to springs, waterholes as well as agricultural lands.)" The practice of "preferential access" described by Marinus has the same characteristics as the practice of "primary users" discussed above. 
Combrink emphasises the informal manner in which different herders and owners of livestock occupy the available grazing on the outer commonages of Leliefontein. ${ }^{45}$ He contends that it is generally accepted by the livestock owners on Leliefontein that they will not encroach on each other's grazing situated at or near a stock post acknowledged as being used exclusively by the herder of a specific flock. ${ }^{46}$ This contention is in line with the observation of Marinus that certain livestock owners have "preferential access" to the grazing and the water resource at specific stock posts ${ }^{47}$ In his discussion of the government's policy to divide the outer commonages on some of the Reserves into private farms, Smith also refers to the detrimental effect the fencing of private farms had on the Reserves, in particular on the informal system of occupation of land at stock posts. He describes this informal system as one where the stock owners negotiated between themselves to decide on their usage rights on the outer commonage for their livestock. ${ }^{48}$ In a more recent study in which the herding practices on Leliefontein were observed and interviews were conducted with livestock owners, herders and agricultural advisers the following was observed with regard to the occupation of stock posts: ${ }^{49}$

Livestock keepers [sic] rights to establish and maintain one or more stockposts were not formally recognised, but once a stockpost was established it was regarded by the rest of the community as being appropriated by the livestock keeper, and may be kept in the family for several generations. However, there are areas of the rangeland where stockposts are established for shorter time periods, and several livestock keepers may establish stockposts here at different times. The area immediately around a stockpost (100-200m radius) is regarded as accessible to that livestock keeper only. Whilst herders are careful not to allow their grazing routes to overlap with those of nearby herds, areas away from the stockpost are not regarded as exclusive.

In this study, the practice with regard to the use of water resources at the stock posts is described as follows: ${ }^{50}$

Water points are usually regarded as being accessible by all. Where these are very closely associated with a stockpost or cropping lands, other herders will establish rights of access with the person regarded as having "ownership" of the area. Access to water is seldom the cause of dispute but may involve a cost paid in the form of a sheep or goat for slaughter. Many dug wells are developed and maintained through cooperative action among herders, whilst wind or solar pumps are established by local authorities but frequently neglected thereafter.

45 Combrink 2004: 54

46 Ibid.

47 According to Salomon 2013: 72, there are 600 stock posts and 169 water points at Leliefontein, which means that several stock posts make use of the same water point.

48 Smith 1996: 7.

49 Allsopp 2007: 746.

50 Ibid. 
It is contended that the informal system of demarcating and occupying grazing at and around stock posts described by the various authors is in fact a manifestation of the customary law system that is still in place at Leliefontein. The exclusive use of an area of land as grazing at or near a water resource by the flock or flocks of a specific group of residents of Leliefontein is a characteristic shared with the communal land use units that were occupied by indigenous communities during the seventeenth and eighteenth centuries. The stock post system at Leliefontein is therefore a modified version of the communal land use units that were occupied by indigenous communities.

\section{Rights in land used as grazing on loan places}

In contrast to customary law systems, where rights in land were obtained by means not directly related to the land, an identifiable and demarcated land unit had to exist before a non-indigenous person could obtain rights therein in terms of RomanDutch law. ${ }^{51}$ The system of describing the land and indicating it on a diagram was introduced in the south-western Cape in 1657 when the Company first gave land to non-indigenous settlers for agricultural purposes. ${ }^{52}$ However, in the interior of the Cape Colony the non-indigenous settlers were livestock farmers and only engaged in agriculture for subsistence purposes. Initially the Company did not exercise any control over the land occupied as grazing by the non-indigenous settlers in the interior of the Cape Colony. After 1703 an informal system of grazing licences developed. This control system was superseded by the loan place system in 1714 . As the land used as grazing on loan places was never surveyed or demarcated before it was allocated to non-indigenous persons it must be accepted that they did not obtain rights in such land in terms of Roman-Dutch law. It is therefore necessary to determine what rights, if any, they obtained in such land and in terms of which rules they obtained such rights. ${ }^{53}$

51 Van der Merwe 1989: 25; Badenhorst 2003: 28-29; Sonnekus 2001: 84; Watermeyer 1914: 37-38; Von Bar 2014: 4-5, 6.

52 Leibbrandt 1900: 262. In this contribution, the words "agriculture" and "agricultural" are used in their original sense of "cultivating the soil to produce crops". The Oxford English Dictionary defines "agriculture" amongst other meanings as follows: "Originally: the theory or practice of cultivating the soil to produce crops; an instance of this (now rare)'. 'agriculture, n." OED Online (Dec 2016) available at http://www.oed.com.uplib.idm.oclc.org/view/Entry/4181? redirectedFrom $=$ agriculture\#teid (accessed 22 Apr 2019).

53 The Company was convinced that the land in the Cape Colony belonged to it. An example of where such ownership was asserted is the resolution of $1 \mathrm{Jul} 1732$, where the owners of allocated land are warned not to cultivate land outside their land beacons on "Comps. grond". Resolutions of the Council of Policy of Cape of Good Hope C. 90. However, in this contribution it is contended that the Company did not have any private law rights in the land in the interior of the Cape Colony. The Company was therefore not able to transfer any rights to the non-indigenous settlers by granting land to them. The contention is based on the fact that the settlement of the interior of the Cape Colony was accomplished by non-indigenous settlers and not by the Company. See Guelke 2003: 94; Theal 1897: 4; Sleigh 2007: 542, 551, 553. 


\section{Precursor of the loan place system}

Colonial government officials recorded the particulars of the grazing licences in a register known as the Oude Wildschutte Boeken. ${ }^{54}$ Its initial purpose was to note the applications lodged by non-indigenous settlers to hunt game. In 1810 an official of the Office of the Receiver-General remarked that he had, in order to try to establish the origins of the loan place system, scrutinised this register. ${ }^{55}$ The grazing licences were granted for varied periods of time, and in some cases the applicants were authorised to grow crops on the land while in other cases they were not. One of the conditions that appeared in all the grazing licences was that the non-indigenous settlers had to respect each other's right to use the grazing and should not encroach on the grazing of another. When encroachment did occur the non-indigenous settlers approached the colonial government to resolve the dispute. One of the heemraden of a district was charged with investigating a complaint made and writing a report on the matter. The colonial government then could either withdraw the offending license or confirm it or ensure that agreement was reached between the parties on how the grazing should be used. ${ }^{56}$ This action was an exercise of the colonial government's power to ensure orderly distribution of grazing between the non-indigenous settlers. This power did not originate from the colonial government's ownership of the loaned land, as asserted by Van der Merwe, ${ }^{57}$ but from its position as sovereign ruler that could authorise its subjects to use land as grazing. The non-indigenous settler who complained about the encroachment on his grazing by another settler who had been issued with a license in the same area was not enforcing a right in land when he complained about the encroachment. He was only holding the colonial government to its undertaking not to issue an authorisation that would cause another non-indigenous settler to encroach on the grazing he used for his livestock. It was not clear from the entries in the register whether the applicants had to pay anything for the authorisations or whether the extent of land that could be used as grazing was specified. ${ }^{58}$

\section{Establishment of the loan place system}

The colonial government received a letter from the Directors of the Company dated 12 August 1713, in which they were urged to find new ways of increasing the revenue of the Cape Colony. ${ }^{59}$ Governor De Chavonnes drew the colonial government's

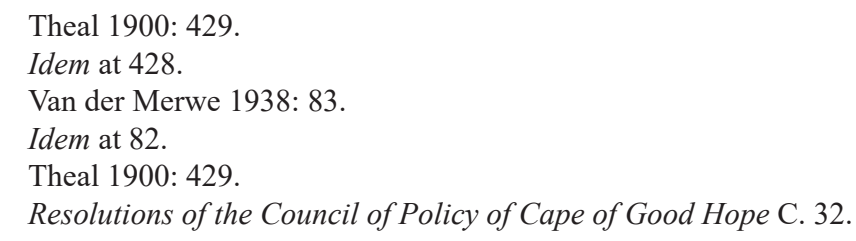


attention to the fact that giving the non-indigenous settlers grazing licences in the interior of the Cape Colony had no financial benefit for the Company ${ }^{60} \mathrm{He}$ requested that the colonial government should consider suitable ways in which the Company could derive some financial benefit from these licences. Therefore, the colonial government decided on 3 July 1714 that the Company should receive something in return from the non-indigenous settlers who had been using land as grazing free of charge since 1703. The colonial government resolved that when the non-indigenous livestock farmers came to request grazing licences in the interior they would be given such land on loan. The colonial government decided to impose a fee to be paid as recognition for the privilege to loan the land in the interior as grazing. ${ }^{61}$

The colonial government's resolution was published in the form of a plakaat. ${ }^{62}$ The plakaat of 3 July 1714 provided that non-indigenous settlers who used land as grazing in the interior of the Cape Colony would in future have to loan the land from the colonial government and pay a recognition fee for the privilege. However, the plakaat did not provide for the manner in which the land used as grazing had to be identified and demarcated. Therefore, although the plakaat provided for the fiscal conditions that had to be met by a non-indigenous settler to occupy a loan place it did not provide for the substantive rights that the occupier of the loan place had in the land he used as grazing. The plakaat merely provided that the non-indigenous person who had paid the recognition fee would be authorised to use the land in the interior as grazing. The loan place system was a unique feature of the land law system of the Cape Colony that was introduced into its the domestic law by the plakaat of 3 July 1714. The loan place system was therefore a creature of statute and was not based on Roman-Dutch law. Consequently, occupation of a loan place did not confer any rights similar to the Roman-Dutch law right of ownership or lease on the occupier. The plakaat was silent on the rights of occupiers. Their rights flowed from the authorisation that they received to use an essentially unlimited territory as grazing for their livestock. ${ }^{63}$ In return for the payment of recognition they received

60 Jeffreys 1948: 31.

61 Ibid.

62 Ibid. Plakaten were a source of law in the Cape Colony. Roos 1897: 10; Roos 1906: 242-243. Wessels endorses the views expressed by Roos. See Wessels 1908: 358-359. Van Zyl 1907: 132133 is of the opinion that Roos was mistaken in his opinion. He wrote a series of articles in the $S A L J$ in which he motivates why the legislation enacted by the colonial government prior to 1795 cannot be regarded as a source of law for the Cape Colony. Botha 1913: 298-299 discusses the divergent views relating to the legislation enacted by the colonial government before 1795 under the subtitle "The common and statute law at the Cape of Good Hope during the 17th and 18 th centuries" in an article in the $S A L J$ entitled "Notes on some controverted points of law". He refers to several cases heard by the Council of Justice in the Cape Colony before 1795 in which reference is made to plakaten enacted by the colonial government. He therefore concludes that legislation enacted by the colonial government before 1795 was regarded as a source of law by the highest court in the Cape Colony. From these remarks it appears that the views expressed by Roos and Wessels must be preferred to that of Van Zyl.

63 Van der Merwe 1938: 108. 
the protection of the colonial government against unfair deprivation of the grazing at or near their homestead.

\section{Transformation of the domestic land law of the Cape Colony}

During the second British occupation the Governor, the Earl of Caledon, became aware of the problems that existed in the Cape Colony with regard to occupation of land and initiated an investigation into land matters. ${ }^{64}$ Reports on the loan place system were prepared by the Office of the Receiver-General of Revenue, the Fiscal of the Cape Colony, JA Truter, and the President of the Court of Justice, WS van Ryneveld. The investigation culminated in the enactment of the Conversion of Loan Places to Perpetual Quitrent Proclamation on 6 August 1813 (Perpetual Quitrent Proclamation) by Governor Cradock.

\section{Abolishment of the loan place system}

According to the Preamble of the Perpetual Quitrent Proclamation its purpose was to improve the cultivation of land in the Cape Colony by giving security of title to the non-indigenous occupiers of loan places by converting loan places into perpetual quitrent tenure farms. ${ }^{65}$ The approach adopted in the Perpetual Quitrent Proclamation was that the extent of the land granted on perpetual quitrent would be the same as the land legally occupied by the non-indigenous settler on loan. However, the extent would not exceed 3000 morgen except if authorised by the governor. ${ }^{66}$ The quitrent that had to be paid was to be determined by "the situation, fertility, and other favourable circumstances of the land" but could not exceed 250 rixdollars per year. ${ }^{67}$ On conversion of a loan place to quitrent the land had to be surveyed before the title deed to the land would be issued to the owner. The landdrost of the district where the land was converted had to send the diagram of the surveyed land to Cape Town and had to certify that no other person had been prejudiced by the survey and that the land did not exceed 3000 morgen. ${ }^{6}$

\section{Implementation of the Perpetual Quitrent Proclamation}

In this contribution it is contended that when the Perpetual Quitrent Proclamation was implemented two misconceptions regarding the existing system of loan places

64 Weaver 2001: 12

65 Jackson 1906a: 12.

66 Idem at 12-13.

67 Idem at 13.

68 Idem at 14 
had the effect that non-indigenous settlers were placed in a much better position with regard to rights in land used as grazing than indigenous communities. The discussion in sections 2 and 3 above shows that the rights in land used as grazing in the interior of the Cape Colony were in essence the same for non-indigenous settlers and indigenous communities. From the perspective of the present constitutional dispensation and land reform programme it is clear that the Perpetual Quitrent Proclamation was racially discriminatory legislation as it disregarded the rights in land conferred on indigenous communities by their customary law systems.

\section{Misconception that loan places were leased to non-indigenous settlers}

The conception of the colonial government that rights of non-indigenous settlers in land used as grazing on loan places could be equated to the rights of a lessee originates with the first report prepared by Truter. He remarks that -

as long as the loan places were only gratuitous concessions the withdrawing of such grants and the ceding of such places to others required nothing more than the simple will of the Government without that the person who for the time had gratis the use of Government ground could, with even a shadow of reason, demand a longer enjoyment of such mere favor $[$ sic $]$ contrary to the will of Government. ${ }^{69}$

Truter therefore contends that, prior to 1714, the rights that the non-indigenous settlers had in the land used as grazing in terms of a grazing license were very insecure. This is evident from his remark that the non-indigenous settlers occupied a the land as a mere favour from the colonial government. According to Truter the plakaat of 3 July 1714 made the rights of the non-indigenous settlers in the loan places more secure as the land was no longer loaned to non-indigenous settlers but leased to them. ${ }^{70}$

In the resolutions of the colonial government that dealt with lease of land to the non-indigenous settlers the Dutch words verhuijren, huirders and huyrder are used throughout. ${ }^{71}$ In the cases where land was loaned the Dutch word leening is used. ${ }^{72}$ This practice clearly illustrates that the colonial government did not regard lease of land and loan of land as the same thing. However, there are more convincing arguments why the plakaat did not change the existing system of grazing licenses into a lease system. These arguments are based on Roman and Roman-Dutch law principles relating to the lease of land. The loan place system that was established in the interior of the Cape Colony did not conform to these principles. De Groot

69 Theal 1901: 95.

70 Ibid. It must be borne in mind that Truter did not make a distinction between the grazing license system and the loan place system instituted from 1714.

71 Resolutions of the Council of Policy of Cape of Good Hope C. 10 and C. 12. The entry for 1 Jan 1659 in Van Riebeeck's Journal also refers to "verhuyring". See Bosman \& Thom 1957: 1.

72 Resolutions of the Council of Policy of Cape of Good Hope C. 14. 
remarks that for a lease to come into existence the thing that is given in hire must be certain. ${ }^{73}$ Cooper sheds light on the requirements that must be met to ensure that the thing is certain. He states that the property must be identified or identifiable. When the measurement of the land can be given, it is sufficiently identified to be susceptible to be leased. ${ }^{74}$ For example, the leases that were granted in terms of the 1732 erfpacht system were in most cases identified by naming the land owned by the lessee and stating what the measurement of the leased land was. ${ }^{75}$ When the land that is to be leased is described by giving the limits or boundaries thereof it is regarded as being identified land. When no description either by measurement or by describing the boundaries can be given of land, such land cannot be leased. ${ }^{76}$ The land used as grazing that was loaned to the non-indigenous settlers could not be described nor could it be measured.

It is contended that because Governor Cradock regarded the loan place system as akin to a lease system he did not find it incongruous to provide in the Perpetual Quitrent Proclamation that the rights in loan places can be converted into ownership. In other words, because Truter wrongly advised the Governor that the non-indigenous settlers were lessees of the colonial government they obtained real rights in land to replace the limited use rights they in fact had in the land.

\section{Misconception regarding the size of loan places}

In the report of the Office of the Receiver-General of Revenue mention is made of the custom that an occupier of a loan place had the exclusive use of the land used as grazing stretching a half-hour's walk in each direction from a central point or beacon on the loan place. It appears that the author of the Receiver-General's report based his contentions on the instructions that the Batavian Governor, General Janssens, issued to field cornets regarding the allocation of loan places to non-indigenous settlers. ${ }^{77}$ In his first report Truter commented on the Receiver-General of Revenue's remarks and refuted the existence of such a custom in the following terms: ${ }^{78}$

Resolutions of the Council of Policy of Cape of Good Hope C. 93. The erfpacht system was introduced to provide non-indigenous agriculturalists the opportunity to lease land adjacent to their existing farms for agricultural purposes.

76 Cooper 1973: 34-35.

77 This custom was described as follows in the field cornet instructions published in 1805: "On inspecting the Land asked for as a Loan Place, the Field-Cornet begins (the Applicant having pointed out the Land) by fixing a middle point, and ascertains whether, in every direction from it, the extent of half an hour can be allowed without touching on the Freehold, Quitrent Land, or Loan Right, of others, or on any Government Land reserved for Uitspan Places, or other public uses." See Harding 1838: 81-82. In this contribution, this instruction is referred to as the half-hour principle.

78 Theal 1901: 99 


\begin{abstract}
It is generally maintained at present that a loan possessor has a right to occupy three hours ground round the middle point of his place, that is half an hour on every side of the same; but however generally this is asserted, and even confirmed by some Magistrates, yet I cannot coincide therein, because there are many places which cannot be extended to an hour in diameter without injuring other places, and, because if there be no law, as is the case, prescribing this distance, there does not exist any [sic] why this distance should be considered as natural; it being moreover necessary to view the business in this light, as otherwise many places must be considered as not having their legal extent, which since many years have been possessed as fully sufficient.
\end{abstract}

Notwithstanding the clear indication by Truter that it cannot be contended that the practice provided for in Janssens' field cornet instructions was intended to indicate that a loan place had a fixed area of grazing allocated to it, Governor Cradock decided that loan places must be converted into farms not exceeding 3000 morgen in size. ${ }^{79}$ That meant that non-indigenous settlers who previously had nothing more than the right to use land as grazing in the interior of the Cape Colony, on the conversion of the loan place became the owner of a surveyed land unit in terms of Roman-Dutch law principles.

\title{
43 Survey, grant and sale of Crown land
}

Once the Cape Colony was formally ceded to the British sovereign in 1814 the colonial government proceeded to grant and sell the waste land ${ }^{80}$ in the Colony. In the period from 1813 to 1843 the provisions of the Perpetual Quitrent Proclamation were applicable to the grants of land made by the colonial government. ${ }^{81}$ In 1840 the British government launched a concerted effort to standardise the land laws of the British Empire. ${ }^{82}$ In order to implement the instructions received from the Colonial Land and Emigration Commissioners the colonial government published the "Conditions and regulations upon which the Crown land at the Cape of Good Hope will be disposed of" (Conditions and Regulations) in the Colonial Government

79 It appears that the size of 3000 morgen was derived from a calculation based on the half-hour principle referred to in $n$ 78. See Weaver 2003: 117; Sampson 1994: 75.

80 In this contribution, the phrase "waste land" means all land before it was occupied in any manner by non-indigenous persons.

81 Although the Perpetual Quitrent Proclamation was only applicable to conversions of loan places, Milton 1996: 667-668 remarks that the courts later made it clear that the Perpetual Quitrent Proclamation was also applicable to original grants of land and not only loan place conversions. In the Report of the Surveyor-General, it is remarked that although the British government was of the opinion that the Perpetual Quitrent Proclamation should only be applicable to the conversion of loan places; the first grants that were made by Cradock were original grants and not loan place conversions. Report of the Surveyor-General on the Tenure of Land, on the Land Laws and Their Results, and on the Topography of the Colony Cape of Good Hope 1876: 23.

82 Christopher 1984: 11. 
Gazette on 7 September $1843 .{ }^{83}$ Paragraph 1 of the Conditions and Regulations provides in peremptory terms that the "unappropriated Crown Lands in this Colony will be sold in Freehold, and by Public Auction only". The Conditions and Regulations provided that applications could be made for a piece of land identified in the application to be put up for sale. After receipt of an application the SurveyorGeneral had to survey the land identified in the application. From paragraph 6 of the Conditions and Regulations it appears that apart from land applied for, the colonial government could also offer land for sale on its own initiative. ${ }^{84}$ Milton remarks that the purpose of the Conditions and Regulations was to establish a uniform land tenure system in the form of freehold tenure in the Cape Colony to bring it in line with the rest of the British Empire. ${ }^{85}$

The first Parliament of the Cape Colony enacted the "Act for Regulating the Manner in which Crown Lands at the Cape of Good Hope shall be disposed of" (1860 Crown Lands Act) which repealed the Conditions and Regulations and replaced it with a system that provided that "all waste and unappropriated Crown lands will be sold subject to an annual quitrent on each lot, and at a reserved price, sufficient at least to defray the costs of inspection, survey, erection of beacons, and title deed". ${ }^{87}$ The 1860 Crown Lands Act reinstated the quitrent system as provided for in the Perpetual Quitrent Proclamation. ${ }^{88}$ Although the 1860 Crown Lands Act did not contain a definition of Crown land several sections provide which land is to be regarded as Crown land and which not. From an analysis of these sections it appears that the legislature regarded all land not occupied by non-indigenous persons within the boundaries of the Cape Colony as being waste Crown land, with the exception of the land assigned by the Governor to the residents of towns and villages to use as pasture. Although the 1860 Crown Lands Act was repealed in 1878 its successor Acts did not add or subtract anything from the description of Crown land in the 1860 Crown Lands Act.

\section{Negative effect of the alienation of Crown land on pastoral indigenous communities}

Pastoral indigenous communities living in the north-western Cape experienced less encroachment on their land than their counterparts in other areas of the Cape Colony. During the nineteenth century the mission stations in this region were not primarily regarded as places of refuge by the indigenous communities who, notwithstanding the intrusion of non-indigenous settlers, were able to keep on occupying land in

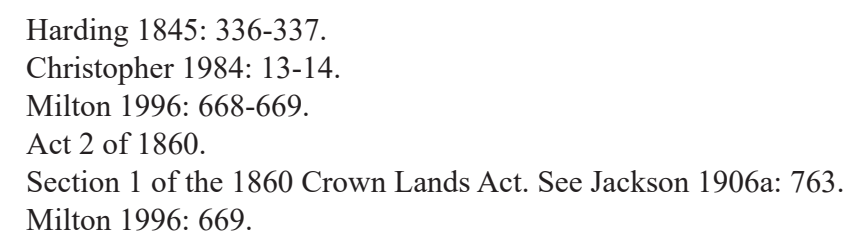


terms of their customary law systems as independent communities. However, these communities found it to their benefit to be under the protection of the missionaries at the mission stations. The missionaries interceded with the British colonial government on behalf of the communities concerned and were instrumental in safeguarding their right to occupy land as grazing and for residential and agricultural purposes at or near the mission stations.

Since the land occupied at mission stations by pastoral indigenous communities was regarded as Crown land, the Governor of the Cape Colony issued Tickets of Occupation to the communities concerned. These Tickets of Occupation included a diagram or a description of the land around the mission stations that was reserved for the exclusive use of the indigenous residents of the mission stations. The land identified in the Tickets of Occupation became the territories of the Reserves that were created in terms of legislation adopted in the twentieth century. ${ }^{89}$ However, the extent of the territory identified in the Tickets of Occupation was in most cases much less than the land used as grazing by the pastoral indigenous communities living at the mission stations. ${ }^{90}$ The legislation dealing with Crown land in the Cape Colony made it possible for the colonial government to dispossess the pastoral indigenous communities of the land outside the boundaries defined in the Tickets of Occupation that they occupied in terms of their customary law systems.

This dispossession of land was an almost invisible process. In his description of the district of Namaqualand, Noble remarks that "there are upwards of one hundred and thirty measured farms and one or two mission stations in the southern part, the produce and stock on which are valued at $£ 180000 " .{ }^{91}$ This means that in 1875 there were already 130 farms held under perpetual quitrent tenure in the north-western Cape. Part of the surveyor's function is to divide and separate the surveyed land from the surrounding land. This is done by placing beacons on the corners of the measured land and depicting the demarcated land on the diagram accompanying a title deed. ${ }^{92}$ However, the beacons placed by the surveyor were not a physical barrier to movement of man and livestock across the measured land. ${ }^{93}$ It was only when fences were erected between these beacons that access to the measured land was restricted. Although the process of fencing of private land around the Reserves was

89 See n 36

90 Sharp \& West 1984: 4.

91 Noble 1875: 86.

92 Denoon 1947: 178.

93 Hill describes the manner in which land was occupied in the Northern Cape during the nineteenth century as follows: "During the 19th century the Cape Colony gave tickets of occupation for land in the vicinity of the missions to the Khoikhoi as a guarantee of permanent occupation. This safeguarded the indigenous people against further encroachment by Europeans (Boonzaier 1987). The missions thus formed the basis for the establishment of the six Coloured Rural Areas (reserves) of Namaqualand. At this time, however, nomadic movement was not contained within the boundaries of the reserves. A system of reciprocity between European farmers and the Khoikhoi facilitated movement of pastoralists over large areas of privatised European land, the reserves and State land" (emphasis added). See Hill 1990: 199. 
only completed in the twentieth century ${ }^{94}$ it is contended that it was the legislation adopted in the Cape Colony during the colonial period that made the dispossession of the land outside the boundaries of the Reserves possible. In other words, because land used as grazing by indigenous communities was regarded as Crown land and could be sold in terms of the legislation discussed in subsection 43 the customary law rights in land of the residents of the Reserves were extinguished.

\section{Contemporary legal developments that hamper the restitution of land dispossessed during the colonial period}

To date, the Richtersveld cases $^{95}$ are the only reported South African court cases in which the residents of a Reserve have succeeded in claiming back the land that was occupied by their ancestors during the colonial period. The Richtersveld community's claim to the land that their ancestors used as grazing before they were dispossessed was granted in terms of the Restitution Act. Notwithstanding the successful claim of the Richtersveld community no other community living on the Reserves has succeeded with a claim for restitution in terms of the Restitution Act. Mostert comments as follows on the limited value that Alexkor has as a precedent for communities in similar circumstances who wish to institute a claim for restitution of their land: ${ }^{96}$

The judgments of both the supreme court of appeal and the constitutional court ensure some kind of justice for the Richtersveld people, without creating any expectations of a broadbased restitution policy for the many other (now) dispersed and incohesive groups, who might have been subjected to an even more disruptive and changeful history, and who might have wanted to rely on the precedent set by the Richtersveld case.

In this contribution it is contended that the reason why Richtersveld 2 and Alexkor are not appropriate precedents for the residents of the Reserves is the approach of

94 Rohde remarks that in the case of Leliefontein the boundaries of the Reserve and the neighbouring privately owned land were not fenced until after the Second World War. See Rohde \& Hoffman 2008: 197, 201, 211. Similarly, Samuels 2013: 49-50 remarks as follows: "In Namaqualand pastoralists were prevented from using white-owned land when privately white-owned farms were fenced off and a camp system was introduced under the Fencing Act, 1912 (Act No 17 of 1912). Fencing also began to replace herding as a livestock management option in the Karoo at this time (Dean et al, 1995). Fencing of private farms adjacent to Leliefontein continued until the 1960s since several private farmers did not want to proceed with erecting fences until the Leliefontein management board paid half of the fencing costs (Leliefontein Management Board Unpublished minutes). Fencing was perceived to increase the carrying capacity of the veld and improved rangeland condition (Archer, 2002)."

95 The phrase "Richtersveld cases" is used as a collective name for all the cases involving the land claim of the Richtersveld community against Alexkor Ltd and the State. In addition to the cases in the Land Claims Court (LCC) and SCA, the CC, in Alexkor, confirmed the decision of the SCA.

96 Mostert \& Fitzpatrick 2004: 321. 
the SCA in Alexkor 2 to the question whether the British Crown became the owner of all land in the Cape Colony.

In Richtersveld Community $v$ Alexkor Ltd ${ }^{97}$ (Richtersveld 1) the LCC decided that the Richtersveld indigenous communities lost their rights in their land when the British government annexed the territory where they lived in $1847 .{ }^{98}$ The LCC remarks that the law in force in the Cape Colony at the time of annexation provided that all land "not granted under some form of tenure belonged to the Crown". ${ }^{99}$ The LCC also relies on Cape Town Town Council v Colonial Government and Table Bay Harbour Board ${ }^{100}$ (Harbour Board) to substantiate its finding with regard to the extinction of the indigenous communities' rights in land in 1847. ${ }^{101}$ In Harbour Board the Supreme Court also accepts as a matter of fact that "the nominal title to all ungranted land remains with the Crown". ${ }^{102}$

The remarks of the LCC in Richtersveld 1 referred to above play an important part in its decision that the Richtersveld community's claim to restitution under the Restitution Act cannot succeed. In essence the LCC found that because all land in the Cape Colony not in private ownership became Crown land the Richtersveld community was dispossessed of their rights in land in 1847. The SCA disposed of the LCC's findings in this regard as follows: ${ }^{103}$

The LCC held that in terms of the law in force in the Cape Colony at the time of the annexation all land not granted under some form of tenure belonged to the Crown (at para [43]). In this regard it relied upon some authors and an obiter statement in Cape Town Council v Colonial Government and Table Bay Harbour Board (1906) 23 SC 62. This view, no doubt, is based upon English feudal law and to the extent that Roman-Dutch law had some remnants of feudal law, that law was never introduced into South Africa.

It is contended that the SCA erred in its finding that the land in the Cape Colony did not become the property of the British Crown. The conduct of the colonial

972001 (3) SA 1293

98 Richtersveld Community v Alexkor Ltd 2001 (3) SA 1293 at 1315.

99 Ibid.

100190623 SC 6269.

101 Richtersveld Community v Alexkor Ltd 2001 (3) SA 1293 at 1315.

102 Town Town Council v Colonial Government and Table Bay Harbour Board at 69.

103 Richtersveld Community v Alexkor Ltd 2003 (6) SA 104 (SCA) at 128-129.

104 An example of the colonial government's conduct is how it dealt with land at Port Nolloth that had been occupied by pastoral indigenous communities for centuries. The purpose of the Port Nolloth Crown Lands Act 33 of 1904 was to enable non-indigenous occupiers of land at Port Nolloth to obtain title in such land. To this end, s 2 of the Port Nolloth Act provided as follows: "Notwithstanding anything to the contrary contained in any Act it shall be lawful, from and after the passing of this Act for the Governor to grant title in favour of such claimants, to such pieces or lots of Crown land at Port Nolloth as the said Commission may recommend." See Jackson 1906b: 4759-4760. From this it is clear that the British colonial government acted as if the land belonged to the British Crown. The Governor was authorised to grant land occupied by pastoral indigenous communities to non-indigenous occupiers in terms of the Port Nolloth Act without any compensation being offered to these communities. 
government when dealing with waste land in the Cape Colony ${ }^{104}$ and the remarks of the colonial courts ${ }^{105}$ clearly show that the English common law doctrine of tenures was incorporated into the domestic law of the Cape Colony. This argument is strengthened by the fact that in Barnett v Minister of Land Affairs ${ }^{106}$ (Barnett) the SCA deemed it necessary to refer to Harbour Board as support for the statement that "the legal principle to be applied is that, since all land originally belongs to the State, land which has never been transferred into private ownership remains State land" ${ }^{107}$

The significance of the SCA not accepting that the British Crown was the owner of all waste land in the Cape Colony, is that the fact that the residents of all the other Reserves in the region have been dispossessed of their rights in land in terms of racially discriminatory legislation or administrative actions is lost sight of. It cannot be equitable to differentiate between indigenous communities or persons who were dispossessed of their rights in land by racially discriminatory legislation or administrative actions. However, the cut-off date and the failure of the SCA to acknowledge that pastoral indigenous communities have been dispossessed of their rights in land by such legislation and actions, differentiate unfairly between descendants of such communities and other indigenous communities.

The courts have perpetuated the inequality between the descendants of pastoral indigenous communities and other indigenous communities caused by the cut-off date. In cases like Prinsloo v Ndebele-Ndzundza Community ${ }^{108}$ (Prinsloo) and Department of Land Affairs $v$ Goedgelegen Tropical Fruits (Pty) Ltd ${ }^{109}$ (Goedgelegen) the courts accepted that the customary law rights in land of indigenous communities were not extinguished even though non-indigenous persons had become the registered owners of the land in question. ${ }^{110}$ Notwithstanding the survey and sale of the land next to the Reserves ${ }^{111}$ in the nineteenth century, in many cases the residents of the Reserves

105 In De Villiers $v$ The Cape, Divisional Council (1875) 5 Buch 50 and Berry $v$ The Divisional Council of Port Elizabeth (1880-1881) 1 EDC 241 (Berry), the courts made it clear that all land in the Cape Colony belonged to the British Crown before it was granted to non-indigenous settlers. In the last mentioned case the court remarked that the Crown as dominus directus had retained rights in the perpetual quitrent land of the plaintiff. The Divisional Council's right to raise material on the perpetual quitrent farm for the purpose of constructing roads is referred to as a paramount right that cannot be equated to an easement or servitude. See Berry v The Divisional Council of Port Elizabeth at 245.

1062007 (6) SA 313 (SCA).

107 Barnett $v$ Minister of Land Affairs at 322.

10820056 SA 144 (SCA).

10920076 SA 199 (CC).

110 In these cases, the claimants continued to reside on the land although they were dispossessed of their customary law rights in the land. Prinsloo $v$ Ndebele-Ndzundza Community at 152-154; Department of Land Affairs v Goedgelegen Tropical Fruits (Pty) Ltd at 213.

111 The residents of the Reserves were dispossessed of their customary law rights in this land because the continued existence of such rights was not compatible with South African common law principles relating to ownership of land as applied through the nineteenth and twentieth centuries up to 1994. 
continued to exercise customary law rights on the privately owned land. However, because they did not reside permanently on the land they used as grazing they were eventually excluded from such land when it was fenced by the owners. Therefore, although both the claimants in Prinsloo and Goedgelegen and the residents of the Reserves were dispossessed of their customary law rights in land, only the claimants were able to remain on the land and, according to the SCA and CC, thus retained their right to claim back their land, while it was impossible for the residents to remain on the land outside the Reserves and they consequently could not claim it back.

\section{Restitution of land dispossessed during the colonial period}

Reversing the effects of colonial dispossession of land must be achieved by adopting the legislation contemplated in section 25(8) of the Constitution, which provides as follows:

(8) No provision of this section may impede the state from taking legislative and other measures to achieve land, water and related reform, in order to redress the results of past racial discrimination, provided that any departure from the provisions of this section is in accordance with the provisions of section 36(1).

The privately owned land that has been acquired and will be acquired by the state in the vicinity of and around the Reserves for the purpose of redistribution should be made available to the residents of the Reserves in terms of legislation made in terms of section 25(8) of the Constitution. Such legislation may, subject to section 25(1) and (2) of the Constitution, provide for a system where land is made available to livestock owners to use as grazing in accordance with the customary law systems used on the Reserves. I contend that the cut-off date is not an impediment to the proposed legislation to be made under section 25(8) of the Constitution as it will redress the results of past racial discrimination and prevent unfair differentiation between different indigenous groups that were all victims of such discrimination.

Legislation made in terms of section 25(8) should take into account that the north-western Cape is an arid region and its resources must be utilised in a sustainable manner. It can be argued that the system of migration of livestock between winter and summer rainfall regions is the most sustainable for the region. In this regard Vetter remarks as follows: ${ }^{112}$

In semi-arid ecosystems, livestock and wildlife need to have access to winter and summer grazing, areas of different vegetation, widely scattered water points and ideally areas of forage reserve in times of drought (Samuels et al 2007). Unlike crop production, livestock farming requires fairly large tracts of land, and sharing a single large area is thus ecologically

112 Vetter 2013: 6 . 
and economically more appropriate than dividing the commons into smaller individual land parcels.

Legislation introducing a system of occupation of land along the lines suggested by Vetter will mean that areas of land will have to be demarcated where the rights of an owner of land, such as a municipality or a communal property association, ${ }^{113}$ will be limited. The ownership rights of such entities will be limited by the residents of the Reserves using land as grazing and water resources in terms of their customary law systems. Such legislation will introduce a significant shift away from the South African common law principles relating to ownership of land.

\section{Conclusion}

It may be contended that the dispossession of the customary law rights in land of the descendants of pastoral indigenous communities has not received the necessary attention because very little is known about the nature of such rights. ${ }^{114}$ In this contribution it is illustrated that the pastoral indigenous communities had welldeveloped customary law systems that regulated the manner in which they occupied land and used available water resources. It is also contended that the residents of the Reserves are still occupying communal land on the Reserves in terms of these customary law systems. In view of the constitutional recognition that is given to customary law it is imperative that the customary law systems of pastoral indigenous communities are also taken into account when dealing with the restitution of dispossessed land.

The rights in land of non-indigenous settlers who occupied loan places before the introduction of the Perpetual Quitrent Proclamation have also not been considered in any great detail. It was accepted that the occupation of a loan place conferred the same rights in land on the occupier that a lessee of land had. This contribution is aimed at countering the notion that non-indigenous settlers had such secure rights in the land they occupied on loan places.

The re-evaluation of the rights in land of pastoral indigenous communities in terms of their customary law systems and the rights in land of non-indigenous settlers in terms of the domestic law of the Cape Colony leads to the conclusion that prior to 1813 non-indigenous settlers and pastoral indigenous communities had essentially the same rights in the land they used as grazing. However, the introduction of the Perpetual Quitrent Proclamation and the subsequent legislation discussed above created a land law system that disregarded the customary law rights in land of pastoral

113 These are the entities who will become the owners of the land transferred in terms of the Transformation Act. See n 37.

114 In this regard it must be noted that some writers on the land question in South Africa have negated the fact that the pastoral indigenous communities did have customary law rights in land. See, eg, the remarks made in Changuion \& Steenkamp 2012: 16. 
indigenous communities. Inevitably, this created an inequitable land law system that was in essence based on difference in race. The application of the domestic law of the Cape Colony to the land occupied by pastoral indigenous communities had the effect that they were dispossessed of their rights in land.

The purpose of this contribution is to show that although there may be good reasons ${ }^{115}$ for the determination of a cut-off date for the purposes of restitution of land it has created unwarranted differentiation between the descendants of pastoral indigenous communities and other indigenous communities living in other parts of South Africa. The approach adopted by the LCC in Alexkor 1 must be accepted as correct. Such an approach will acknowledge that pastoral indigenous communities have been dispossessed of their customary law rights in land prior to the cut-off date by the racially discriminatory legislation and actions of the British colonial government.

It is suggested that the unique nature of the customary law systems of pastoral indigenous communities as discussed in this contribution will render the complicated qualification system of the Restitution Act unnecessary for the purposes of the suggested legislation to be made in terms of section 25(8) of the Constitution. It must be accepted that the ancestors of the residents of the Reserves were dispossessed of their customary law rights in land. It is therefore not necessary to define and identify communities that may qualify for restitution of their land. It is submitted that if the residents of the Reserves are still occupying land in terms of customary law systems on the Reserves they must be authorised by the proposed legislation to exercise these rights on the land their ancestors occupied as grazing outside the boundaries of the Reserves.

\section{Bibliography}

Allsopp, $\mathrm{N}$ et al (2007) "Environmental perceptions and practices of livestock keepers on the Namaqualand Commons challenge conventional rangeland management" $J$ of Arid Environments 17: 740-754

Badenhorst, PJ et al (2003) Silberberg and Schoeman's The Law of Property (Durban)

Boonzaier, E et al (1996) The Cape Herders: A History of the Khoikhoi of Southern Africa (Cape Town)

Bosman, DB \& Thom, HB (1957) Daghregister gehouden by den oppercoopman Jan Anthonisz van Riebeeck Deel III 1659-1662 (Kaapstad)

Botha, CG (1913) "Notes on some controverted points of law" SALJ 30: 289-299

Changuion, L \& Steenkamp, B (2012) Disputed Land. The Historical Development of the South African Land Issue, 1652-2011 (Pretoria)

115 See the White Paper on South African Land Policy April 1997 at 77-78: available at http://www. ruraldevelopment.gov.za/phocadownload/White-Papers/whitepaperlandreform.pdf (accessed 25 Jan 2019). 


\section{HISTORY OF THE DISPOSSESSION OF THE RIGHTS IN LAND}

Christopher, AJ (1984) The Crown Lands of British South Africa 1853-1914 (Kingston)

Colony of the Cape of Good Hope Acts of Parliament Sessions of 1908, Being the First and Second Sessions of the Twelfth Parliament (1908)

Combrink, AP (2004) "Weidingsbestuur in 'n semi-ariede omgewing met GIS: Paulshoek gevallestudie" (unpublished Masters dissertation, University of Stellenbosch)

Cooper, WE (1973) The South African Law of Landlord and Tenant (Cape Town)

Denoon, G (1947) "Diagrams and remainders (I)" SALJ 64: 178-188

Elphick, R (1977) Kraal and Castle: Khoikhoi and the Founding of White South Africa (New Haven)

Gilbert, J (2007) "Nomadic territories: A human rights approach to nomadic peoples' land rights" Human Rights LR 7: 681-716

Guelke, L (2003) "The tragedy of privatisation: Some environmental consequences of the Dutch invasion of Khoikhoi South Africa" South African Geographical J 85: 90-98

Guelke, L \& Shell, R (1992) "Landscape of conquest: Frontier water alienation and Khoikhoi strategies of survival, 1652-1780" J of Southern African Studies 18: 803-824

Harding, W (1838) The Cape of Good Hope Government Proclamations, from 1806 to 1825, as Now in Force and Unrepealed; and the Ordinances Passed in Council, from 1825 to 1838 vol I (Cape Town)

Harding, W (1845) The Cape of Good Hope Government Proclamations, from 1806 to 1825, as Now in Force and Unrepealed; and the Ordinances Passed in Council, from 1825 to 1844 vol III (Cape Town)

Hattingh, L (2016) "Die Kaapse Koina" in De Wet, C et al (eds) Die VOC aan die Kaap 16521795 (Pretoria)

Herbst, M \& Du Plessis, W (2008) "Customary law v common law marriages: A hybrid approach in South Africa" Electronic J of Comparative Law 12: 1-15

Hill, R et al (1990) "Conflict over change in land tenure in the reserves of Namaqualand, South Africa: A role for integrated environmental management” Impact Assessment 8: 197-215

Hinz, MO \& Grasshoff, A (eds) (2016) Customary Law Ascertained Volume 3: The Customary Law of the Nama, Ovaherero, Ovambanderu, and San Communities of Namibia (Windhoek)

Jackson, EM (1906a) Statutes of the Cape of Good Hope 1652-1905 vol I 1652-1879 (Cape Town)

Jackson, EM (1906b) Statutes of the Cape of Good Hope 1652-1905 vol III 1894-1905 (Cape Town)

Jeffreys, KM et al (1948) Kaapse Argiefstukke: Kaapse Plakkaatboek Deel II (1707-1753) (Kaapstad)

Kerr, RM (1876) The Commentaries on the Laws of England of Sir William Blackstone, Vol II (London)

Lee, RW (1926) The Jurisprudence of Holland by Hugo Grotius Vol I (Oxford)

Leibbrandt, HCV (1900) Precis of the Archives of the Cape of Good Hope: Letters Despatched from the Cape,1652-1662 Volume III (Cape Town)

Marinus, TW (1998) 'Reforming 'structures of governance' and 'institutions for governance' - learnings for tenure reform which can be drawn from Namaqualand" in Barry, M (ed) Proceedings of the International Conference on Land Tenure in the Developing World with a Focus on Southern Africa (Cape Town) 


\section{JN MCLACHLAN}

Milton, JRL (1996) “Ownership” in Zimmermann, R \& Visser, D (eds) Southern Cross: Civil Law and Common Law in South Africa (Kenwyn)

Mostert, H \& Fitzpatrick, P (2004) “'Living in the margins of history on the edge of the country' - Legal foundation and the Richtersveld community's title to land (part 1)" TSAR: 309-323

Noble, J (1875) Descriptive Handbook of the Cape Colony: Its Condition and Resources (Cape Town)

Olivecrona, K (1974) “Locke's theory of appropriation” in The Philosophical Quarterly (1950-) 24: $220-234$

Rohde, RF \& Hoffman, MT (2008) "One hundred years of separation: The historical ecology of a South African 'Coloured Reserve"” Africa 78: 189-222

Roos, J de V (1897) “The Plakaat Books of the Cape” Cape LJ 14: 1-23

Salomon, M et al (2013) "The good shepherd: Remedying the fencing syndrome" African J of Range \& Forage Science 30: 71-75

Samuels, MI (2013) "Pastoral mobility in a variable and spatially constrained South African environment" (unpublished doctoral thesis, University of Cape Town)

Sampson, CG et al (1994) "An early Dutch settlement pattern on the North East frontier of the Cape Colony" Southern African Field Archaeology 3: 74-81

Schapera, I (1930) The Khoisan Peoples of South Africa: Bushmen and Hottentots (London)

Sharp, J \& West, M (1984) "Controls and constraints: Land, labour and mobility in Namaqualand" Carnegie Conference Paper no 71

Sleigh, D (2007) Die Buiteposte: VOC-buiteposte onder Kaapse Bestuur 1652-1795 (Pretoria)

Smith, AB (1984) "Environmental limitations on prehistoric pastoralism in Africa" The African Archaeological Review 2: 99-111

Smith, H (1996) "Namaqualand and challenges to the law: Community resource management and legal frameworks" Conference paper delivered at the Voices from the Commons, the Sixth Biennial Conference of the International Association for the Study of Common Property

Sonnekus, JC (2001) "Grondeise en die klassifikasie van grond as res nullius of as staatsgrond" TSAR: $84-114$

Theal, GM (1897) History of South Africa under the Administration of the Dutch East India Company [1652-1795] Vol I (London)

Theal, GM (1900) Records of the Cape Colony from May 1809 to March 1811 (London)

Theal, GM (1901) Records of the Cape Colony from March 1811 to October 1812 (London)

Van der Merwe, CG (1989) Sakereg (Durban)

Van der Merwe, PJ (1938) Die Trekboer in die Geskiedenis van die Kaapkolonie 1657-1842 (Kaapstad)

Van Zyl, CH (1907) "The Batavian and the Cape plakaten. An historical narrative" SALJ 24: 132-147

Vetter, S (2013) "Development and sustainable management of rangeland commons - aligning policy with the realities of South Africa's rural landscape" African $J$ of Range \& Forage Science 30: 1-9 


\section{HISTORY OF THE DISPOSSESSION OF THE RIGHTS IN LAND}

Von Bar, C (2014) "Why do we need grundstücke (land units), and what are they? On the difficulties of divining a European concept of 'thing' in property law" Juridica International 22: 3-15

Watermeyer, EF (1914) “Mr. Justice Watermeyer's judgment in Visser v. Du Toit” SALJ 31: 36-41

Weaver, JC (2001) "Exploitation by design: The dismal science, land reform, and the Cape Boers, 1805-22" The J of Imperial and Commonwealth History 29: 1-32

Weaver, JC (2003) The Great Land Rush and the Making of the Modern World (Montreal)

Webley, L (1986) "Pastoralist Ethnoarchaeology in Namaqualand" Goodwin Series 5: 57-61

Wessels, JW (1908) History of the Roman-Dutch Law (Grahamstown)

White Paper on South African Land Policy April 1997 available at http://www.ruraldevelopment. gov.za/phocadownload/White-Papers/whitepaperlandreform.pdf (accessed 25 Jan 2019)

Yanou, MA (2005) "Access to land as a human right: The payment of just and equitable compensation for dispossessed land in South Africa" (unpublished doctoral thesis, University of Rhodes)

\section{Table of cases}

Alexkor Ltd v The Richtersveld Community 2004 (5) SA 460 (CC) 481

Barnett v Minister of Land Affairs 2007 (6) SA 313 (SCA)

Berry v The Divisional Council of Port Elizabeth (1880-1881) 1 EDC 241

Bhe v Magistrate, Khayelitsha, (Commission for Gender Equality as Amicus Curiae); Shibi v Sithole; South African Human Rights Commission v President of the Republic of South Africa 2005 (1) SA 580 (CC)

Cape Town Council v Colonial Government and Table Bay Harbour Board 190623 SC 62

Department of Land Affairs v Goedgelegen Tropical Fruits (Pty) Ltd 20076 SA 199 (CC)

De Villiers $v$ The Cape, Divisional Council (1875) 5 Buch 50

Prinsloo v Ndebele-Ndzundza Community 20056 SA 144 (SCA)

Richtersveld Community v Alexkor Ltd 2001 (3) SA 1293

Richtersveld Community v Alexkor Ltd 2003 (6) SA 104 (SCA)

\section{Legislation}

Act for Regulating the Manner in which Crown Lands at the Cape of Good Hope Shall be Disposed of 2 of 1860

Communal Property Associations Act 28 of 1996

Constitution of the Republic of South Africa, 1996

Mission Stations and Communal Reserves Act 29 of 1909 (Cape of Good Hope)

Natives Land Act 27 of 1913

Port Nolloth Crown Lands Act 33 of 1904

Restitution of Land Rights Act 22 of 1994 


\section{JN MCLACHLAN}

Rural Areas Act (House of Representatives) 9 of 1987

Rural Coloured Areas Act 24 of 1963

Rural Coloured Areas Law 1 of 1979

Transformation of Certain Rural Areas Act 94 of 1998 